Гаценко І. Розвиток мовних компетенцій майьутніх фахівців ...

УДК 808.3:378.14

DOI https://doi.org/10.24919/2308-4863/34-2-13

Ірина ГАЦЕНКО,

orcid.org/0000-0002-9056-4744

кандидат філологічних наук, дочент,

доиент кафедри філософії і суспільних наук

Національного університету "Чернігівська політехніка»

(Чернігів, Україна) airinen@ukr.net

\title{
РОЗВИТОК МОВНИХ КОМПЕТЕНЦЙ МАЙБУТНІХ ФАХІВЦІВ ЮРИДИЧНОГО ПРОФІЛЮ У ПРОЦЕСІ ВИВЧЕННЯ ДИСЦИПЛІНИ «ФАХОВА УКРАЇНСЬКА МОВА»
}

\begin{abstract}
У статті розглядаються ключові питання, пов'язані з професійною підготовкою майбутніх фахівців юридичного профілю в рамках формування культури ділового спілкування у процесі вивчення дисципліни «Фахова украӥнська мова». Представлені теоретичні та практичні аспекти навчання студентів-юристів культурі мовного професійного спілкування, показані способи формування лінгвістичної компетентності та шляхи розвитку творчого потенціалу особистості студента.

Зазначено, щуо формування професійної компетениії юриста на сучасному етапі розвитку вищої школи не можливе без інтеграиії в загальну систему підготовки мовної освіти. Звернено увагу на необхідність створення нової теоретико-методологічної бази професійної підготовки майбутніх фахівиів насамперед у процесі вивчення гуманітарних дисциилін. Зазначено, щзо важливим завданням є підготовка компетентного спеціаліста - особистості, яка має високий рівень комунікативної компетениії.

У статті досліджено завдання, методи і форми навчальної дисципліни «Фахова українська мова». Окреслено иляхи формування мовної компетенції майбутніх фахівців юридичного профілю у процесі викладання дисципліни «Фахова украӥнська мова». Запропоновано шляхи удосконалення мовної підготовки студентів з урахуванням правової специфіки. Зазначено, щзо професійна компетентність є важливим фактором, який дозволяє випускнику адекватно інтегруватися у соціальний простір і, займаючись певного роду діяльністю, спрямувати свій вплив на сочіальне середовище і різні суспільні відносини.

Навчання професійному спілкуванню має бути спрямоване на формування комунікативної компетентності, яка означає здатність здійснювати мовну діяльність засобами мови, правильно використовувати систему мовних і мовленнєвих норм і вибирати комунікативну поведінку відповідно до иілей $і$ ситуацї спілкування в межах професійної сфери діяльності. У дослідженні доведено, щуо на сучасному етапі завданням правової освіти є створення нової функціональної системи підготовки висококваліфікованого фахівия в галузі юриспруденції.

Ключові слова: професійна підготовка, майбутні юристи, культура ділового спілкування, лінгвістична компетенція, мовна культура студента, мовна особистість.
\end{abstract}

Iryna HATSENKO, orcid.org/0000-0002-9056-4744

Candidate of Philological Sciences, Associate Professor, Associate Professor at the Department of Philosophy and Social Sciences Chernihiv Polytechnic National University (Chernihiv,Ukraine) airinen@ukr.net

\section{DEVELOPMENT OF LANGUAGE COMPETENSES OF FUTURE SPECIALISTS OF LEGAL PROFILE IN THE PROCESS OF STUDY OF DISCIPLINE "PROFESSIONAL UKRAINIAN"}

The key questions related to professional preparation of future specialists of legal profile within the framework of forming of culture of business communication in the process of study of discipline "Professional Ukrainian" are examined in the article. In the articles presented theoretical and practical aspects of studies of students-lawyers to the culture of language professional communication, shown methods of forming of linguistic competence and ways of development of creative potential of personality of student.

It is marked that a professional competence is a meaningful factor, that allows to the graduating student to be adequately integrated in social space and occupying certain family by activity, to point the influence at a social environment and different public relations. Studies to professional communication must be sent to forming of communicative competence that means ability to carry out language activity facilities of language, correctly to use the system of language and speech norms and choose communicative behavior in accordance with aims and situation of communication within the limits of professional sphere of activity. 
It is noted that the orientation of the educational process is on the active creative mental work of law students in the context of the development of their analytical and constructive skills should become the most significant component of modern methods of language learning in the specialty. In this regard, the problem of substantiation and development of theoretical and methodological and methodological bases of professional training of graduates of higher educational institutions within the formation of a culture of business communication, really necessary for the successful solution of pressing problems of sustainable development, legality and inadmissibility of violations.

Law and order, implementation of legal reforms and formation of legal cooperation at the international level. It is well-proven during research, that on the modern stage to the tasks of legal education there is creation of the new functional system of preparation of highly skilled specialist in industry of jurisprudence.

Key words: professional preparation, future lawyers, culture of business communication, linguistic competence, language culture of student, language personality.

Постановка проблеми. На сучасному етапі розвиток нашої держави розглядається в загальному контексті міжнародної інтеграції, розширення політичних, економічних i культурних зв'язків із зарубіжними країнами, входження до світового співтовариства правових держав. Успішна реалізація цього процесу в освітній системі залежить від формування освіченої, висококваліфікованої, творчої особистості майбутнього фахівця, готового до продуктивного ділового спілкування, у тому числі і на міжнародному рівні.

У період оновлення всіх аспектів життєдіяльності суспільства і розширення міжнародних зв'язків рівень підготовки фахівця в таких галузях як правознавство визначається сформованістю його особистісних якостей і професійних умінь, серед яких особливе місце займає культура ділового спілкування як основа його професійної мовної підготовки. Для фахівців у галузі юриспруденції, професійна діяльність яких передбачає інтенсивну соціально-психологічну взаємодію, комунікативні контакти, ефективне ділове спілкування мають велике значення. У зв'язку з цим 3 особливою гостротою постає проблема обгрунтування і розробки теоретико-методологічних і методичних основ професійної підготовки випускників вищих навчальних закладів у межах формування культури ділового спілкування, необхідної для успішного вирішення актуальних проблем сталого розвитку суспільства, дотримання законності та неприпустимості порушення правопорядку, впровадження правових реформ i формування правового співробітництва на міжнародному рівні.

Метою будь-якої професійної освіти є досягнення майбутнім фахівцем, у тому числі юристом, високого рівня професійної компетентності. Для того, щоб ця мета була реалізована, необхідна наявність адекватної підготовки у вищому навчальному закладі. Формування професійної компетенції юриста на сучасному етапі розвитку вищої школи не можливе без інтеграції у загальну систему підготовки мовної освіти. У зв'язку 3 цим актуальності набули проблеми перебудови чинної системи підготовки майбутніх юристів як фахівців, які отримали сучасні спеціальні знання, 3 високим рівнем культури, моральності, професійної етики, які повинні здійснювати свою діяльність щодо захисту прав і законних інтересів клієнта з урахуванням публічного статусу держави.

Нині повинна бути визначена нова модель професіонала, яка б відповідала вимогам майбутнього. У такому контексті змінюється роль вищої юридичної освіти як основного інструменту, за допомогою якого фахівець отримує не тільки належну професійну кваліфікацію, а й стає професіоналом із такими високими моральними ідеалами як повага до прав і свобод людини відповідно до вимог Болонського процесу.

Головною метою сучасної юридичної освіти повинна стати підготовка кваліфікованих кадрів, які будуть підтримувати принципи верховенства права, прагнення до демократіі, побудови правової держави, що потребує докорінних змін у змісті та якості освіти. У зв'язку з цим актуальною стає проблема створення нової теоретико-методологічної бази професійної підготовки майбутніх фахівців насамперед у процесі вивчення гуманітарних дисциплін. Грамотний відбір змісту навчання, врахування професійної специфіки, особливостей предметної галузі функціонування мови спеціальності є одним із чинників, які сприяють ефективній організації навчального процесу.

На сучасному етапі проблема розробки методологічних підходів до педагогічних досліджень у теорії і практиці професійної освіти викликає багато наукових суперечок. Коли ми говоримо про професію юриста, то маємо на увазі не просто необхідність володіння культурою мовного професійного спілкування, а й те, що професійна компетентність, зміст якої по-різному розуміють вчені, включає в себе лінгвістичні знання, у тому числі про використання мови в різних ситуаціях. У такому випадку поняття компетенції трактується як здатність застосовувати знання, вміння та особистісні якості для успішної діяльності в певній галузі. Останнім часом мовна підготовка фахівців 
розглядається як найважливіший елемент професійної освіти, оскільки цього вимагають сучасні стандарти ділових комунікацій. Формування професійної компетенції юриста на сучасному етапі розвитку вищої школи не можливе без інтеграції у загальну систему підготовки мовної освіти.

Аналіз досліджень. Проблеми навчання професійному мовленню знайшли обгрунтування у наукових працях багатьох лінгвістів. На особливу увагу заслуговують наукові розвідки мовознавців, які досліджували дидактичні положення організації навчального процесу у ВН3 (С. Архангельський, Ю. Бабанський, В. Вергасов, Л. Виготський, І. Дроздова), комунікативно-діяльнісний підхід до навчання мови (М. Вашуленко, В. Краєвський, О. Лисенко, В. Мельничайко, М. Пентилюк, К. Плиско, М. Скаткін, А. Супрун, Г. Шелехова).

Мета статті - розглянути ключові питання, пов'язані з професійною підготовкою майбутніх фахівців юридичного профілю в рамках формування культури ділового спілкування у процесі вивчення дисципліни «Фахова українська мова».

Виклад основного матеріалу. Володіння усним і письмовим словом стає суттєвою ознакою ділової кваліфікації юриста. Істотним показником освіченості, інтелектуального розвитку сучасного фахівця вгалузі праваєздатність застосовуватизнання ділового мовлення у професійній діяльності. В умовах орієнтації вищої освіти на всебічний і гармонійний розвиток особистості, посилення зв'язку змісту навчання з обраною професією особливого значення для формування мовної й мовленнєвої компетенції студентів набуває вдосконалення змісту вищої освіти (Дроздова, 2001: 1).

Надзвичайно актуальною $є$ проблема формування мовної компетенції студентів юридичних факультетів, тому у програму навчання введена дисципліна «Фахова українська мова», викладання якої сприяє формуванню i розвитку комунікативно-мовленнєвої компетентності, підвищенню культури мовлення, але не вирішує проблему професійної комунікативної компетентності фахівця загалом. Тому говорити, що нині студенти-юристи, які закінчили ВН3, на належному рівні володіють основами професійного мовного спілкування, на жаль, не можна. Найчастіше лінгвістична освіта студентів обмежується культурно-мовною спрямованістю і не завжди усвідомлюється ними як нагальна потреба, яка породжує специфічні проблеми в їхній професійній діяльності.

Спеціаліст правових сфер повинен усвідомлювати, що слово - не тільки комунікативне та естетичне явище, але і знаряддя. Невміле користування ним може призвести до тяжких моральних і навіть юридичних наслідків. Мовне шахрайство (наприклад, при складанні текстів угод, договорів) ставить перед кожним громадянином питання про його правовий захист. Тому фахівці у цих галузях мають навчитися ставитися до слова не лише 3 позиції «правильно / неправильно», а й уміти розглядати мовні факти з точки зору права.

Основна причина формування професійної мови - необхідність у максимально точній передачі спеціальної інформації. Це стосується усіх мов спеціальностей, але для мови юриспруденції має особливе значення. Останніми десятиліттями мова юриспруденції незмінно привертала увагу лінгвістів. Якщо говорити про правову сферу, то варто зазначити, що всередині мови юриспруденції функціонують мовні одиниці, які істотно відрізняються одна від одної і обслуговують різні галузі права, найважливіші з яких державне, конституційне, цивільне, кримінальне, адміністративне.

Процеси взаємопроникнення різних наукових дисциплін призвели до інтенсивного дослідження в галузі зіткнення лінгвістики і спеціальних дисциплін, наприклад юриспруденції. На стику мови і права виникає величезна кількість складних суміжних проблем, які ще необхідно усвідомити й оцінити, знайти їм вирішення, яке задовольняє і лінгвістів, і фахівців із юриспруденції. Для фахівців саме цієї сфери важливі широкі лінгвістичні знання і мовленнєві вміння, оскільки правознавча діяльність багато в чому залежить від уміння ними користуватися, оскільки мова $є$ знаряддям юридичної діяльності.

До професійної діяльності юристів насамперед належить складання документів. Тому основним критерієм професійної мови фахівця має бути нормативність, яка розуміється як точність, правильність, чистота мови. 3 урахуванням завдань кримінального та цивільного судочинства культуру писемного мовлення юриста можна визначити як вибір і організацію мовних засобів, які відповідають вимогам законодавства України та адекватно відображають встановлені в юридичній справі фактичні дані. У процесуальних актах оптимальними є засоби офіційно-ділового стилю, у яких використовується значна кількість готових, стандартних висловів - кліше.

Уміння говорити грамотно - обов'язок кожної людини, особливо юриста. Будь-яке порушення норм мови викликає негативну реакцію, недовіру, відволікає від сприйняття матеріалу, а допущені мовні помилки дискредитують юриста. Якщо помилка залишилася непоміченою, то юрист виявляється провідником мовного безкультур'я. Тому можна стверджувати, що мовна культура - це не 
лише особиста справа кожного юриста. Студенти повинні зрозуміти, що проблеми мовної компетенції порушуються самим життям, практичною необхідністю. Шанобливе ставлення до мови, чиста, правильна, багата мова юриста - це показник його поваги до законів нашої держави. Грамотного фахівця відрізняють глибина та ясність думки, логічність і аргументованість мови, вміння знаходити в кожному конкретному випадку потрібні слова для передачі думок, вміння грамотно оформляти висловлювання.

Для того, щоб оволодіти культурою мовної поведінки, студентам юридичних факультетів необхідно знати вимоги, які висуваються до мови юриста. Перша важлива ознака культури мови - ясність. Це глибоке знання матеріалу, чітка композиція мови, логічність викладу, переконливість аргументів. Досягти ясності і простоти мови можна тільки наполегливою працею над кожною промовою. Часто мова стає неясною через недоречне використання в ній іншомовних слів і вузькоспеціальних термінів. Причиною помилок у мовленні може бути недоречне використання займенників, багатослівність.

Ясність вираження думки призводить до такої якості мови як точність. Точність мови найчастіше пов'язують із точністю слововживання, яка залежить від того, наскільки мовець знає предмет мовлення, наскільки ерудований, чи вміє логічно мислити, чи знає правила української мови. Точність досягається вживанням юридичних термінів і кліше. Неточність мови завжди виникає при вживанні іншомовних слів без урахування їхнього значення, наприклад: інфлячія - девальвачія, апробувати - випробувати.

Слова характеризують промовця як особистість, тому його мова повинна бути чистою. Чистою вважається така мова, у структурі якої немає чужих літературній мові фразеологізмів, діалектної, жаргонної і просторічної лексики. «Працюючи над збагаченням лексичного запасу студентів юридичних спеціальностей професійною термінологією, необхідно звертати увагу на особливості вимови та правопису юридичних термінів; їхнє походження та значення; структурні особливості; доречність використання термінів і професіоналізмів у різних мовних ситуаціях; вживання термінів-синонімів (дублетів - власне українського слова та інтернаціоналізмів) у фахових текстах; особливості перекладу стійких термінологічних сполук, які не мають точних українських відповідників» (Лисенко, 2015: 35).

Однією з основних якостей мови юриста, що визначає іiі ефективність, є правильність, яка передбачає дотримання загальноприйнятих норм літературної мови. Мовні норми - це найбільш поширені, прийняті на практиці і регламентовані правилами варіанти вимови, вживання слів, правопису, постановки розділових знаків. Норми мови характеризуються відносною стійкістю, обов'язковістю. Студенти повинні зрозуміти, що важливо дотримуватися лексичних норм, які забезпечують точність слововживання; орфоепічних і акцентологічних норм, що зумовлюють єдність звукового оформлення мови. Граматичні норми встановлюють одноманітність форм словозміни і з'єднання слів у словосполученні i реченні. Стилістичні норми забезпечують доречність у мові емоційно і функціонально забарвлених мовних засобів. Досить часто у мові студентів доводиться спостерігати порушення синтаксичних норм, зокрема норм керування.

Які кроки має зробити студент для того, щоб лінгвістична компетенція стала складником його професійної компетенції? Перш ніж навчитися говорити, необхідно навчитися мислити. Варто накопичувати знання, читати літературу, вивчати принципи побудови мови, опановувати знання в галузі культури мови. Необхідно і дуже корисно, на нашу думку, якомога частіше виступати 3 публічною промовою на семінарах, конференціях, під час проведення круглих столів, брати участь у дебатах і обговореннях. Це допоможе виробити впевненість у собі, зрозуміти свої помилки, виправляти їх. Допомогу у навчанні надасть обов'язковий аналіз кожного виступу, промови, у яких необхідно визначати успіхи та проаналізувати причини невдач.

Навчання мови юриспруденції не повинно обмежуватися вивченням професійного та термінологічного складників. Це одна із небагатьох мовних сфер, які мають виражений комплексний характер і потребують урахування базової культури особистості і суспільства загалом. Мова юриспруденції має вивчатися і репрезентуватися у навчальному процесі як комплексне соціолінгвістичне і культурологічне явище. Тому формування лінгвістичної компетенції студентів-юристів - багатоаспектне i надзвичайно актуальне питання 3 точки зору лінгвістики і мовної освіти майбутніх фахівців.

Для юриста пріоритетним є вміння зрозуміти і передати інформацію, оскільки його діяльність безпосередньо пов'язана зі встановленням контактів, спілкуванням у соціумі, роботою 3 потоками інформації. Необхідні вміння та навички включають впевненість і швидкість мови, вміння організувати і структурувати інформацію. Як показують дослідження, керівники юридичних установ часто стикаються 3 проблемою неефек- 
Гаценко I. Розвиток мовних компетенцій майьутніх фахівців ...

тивності діяльності нових співробітників. Причиною цього досить часто є саме несформованість у працівника комунікативної компетентності.

Вивчення фахової мови покликане забезпечити формування такої універсальної (загальнокультурної) компетенції як уміння аргументовано, правильно та зрозуміло будувати усну письмову мову, здатність чітко й виразно висловлювати думку, використовувати знання законів техніки мовлення, створювати і редагувати тексти професійного призначення, аналізувати логіку міркувань і висловлювань, мати навички побудови публічної і наукової промови. Крім того, сучасні випускники-юристи зазнають серйозних труднощів у сфері професійного спілкування з колегами і клієнтами, під час ведення ділового листування.

Це не означає, що студенти юридичних спеціальностей під час вивчення дисципліни «Фахова українська мова» вивчатимуть не українську мову, а тільки іiї професійний варіант. Відсутність у змісті навчання матеріалів із культури, політики (як і їхнє безсистемне або занадто широке використання на практичних заняттях) істотно знижує не тільки загальну, але й професійну мотивацію до навчання у студентів. Під час викладання дисципліни «Фахова українська мова» необхідно враховувати, що політична, соціально-економічна ситуація вимагає від майбутнього фахівця швидкої реакції на зміни, які відбуваються, і здатності до гнучкої адаптації у професійній діяльності.

Визначивши основні компоненти змісту професійно й особистісно спрямованого навчання ділового мовлення студентів юридичного профілю, перейдемо до відбору й організації навчального матеріалу. Професійна спрямованість змісту навчання ділового мовлення реалізується через відбір конкретного мовного матеріалу з урахуванням особливостей одержуваної студентами професії. Отже, лексика повинна відбиратися відповідно до критеріїв, бути такою, яка найбільш часто зустрічається в юридичній сфері спілкування. Якщо матеріал не має безпосереднього практичного значення, то ефективність його засвоєння знижується, знижується і рівень сформованості професійної компетенції. 3 усього викладеного вище можна зробити висновок, що необхідно кардинально переглянути змістовний складник робочої програми 3 дисципліни «Фахова українська мова» для юридичних спеціальностей (напрямів), а також якісно змінити склад завдань, які наповнюють практичні вправи та тестові завдання, спираючись на професійну орієнтацію. Для студентів юридич- них спеціальностей, на нашу думку, необхідно включати до практичних занять теми на зразок «Мовна компетенція сучасного юриста». Завдання навчання повинні бути спрямовані на максимальне розкриття таких можливостей студентів.

Особливу увагу необхідно приділяти розвитку навичок створення як письмового, так і усного тексту. Досягти максимального ефекту в досить стислі терміни допомагає спрямованість викладача на виявлення цілей навчання, відбір навчального матеріалу, а також розробку нових методів викладання. Однією $з$ основних цілей кожного викладача $\epsilon$ постійна орієнтація на специфіку спеціальності при роботі з усіма рівнями мови. У цьому випадку ми маємо справу зі студентами, які після закінчення вишу працюватимуть не тільки 3 вітчизняною та міжнародною правовою документацією, а й регулярно стикатимуться 3 безліччю службових інструкцій та інших документів, створюватимуть і сприйматимуть тексти, які визначають правові відносини у суспільстві.

Перший і основний принцип навчання української мови за фахом - тісна співпраця з викладачами спеціальних кафедр і відбір, методична обробка і формулювання завдань, спрямованих на мову спеціальності. Викладач повинен здійснювати добірку спеціальних юридичних текстів, із якими вже працював і які будуть поступово ускладнюватися, а також наочні зразки, які допомагають розбирати помилки, найбільш поширені при створенні текстів за фахом. Також викладач повинен звертати увагу на основні мовні закономірності, які зустрічаються у фахових текстах. Також виникає необхідність із першого заняття працювати зі словником спеціальності, оскільки студенти повинні «зануритися» у професійну мовну сферу. Можна говорити про лексичний банк, із яким працюватимуть студенти. Ще одне завдання, яке ставить перед собою викладач дисципліни «Фахова українська мова», - це навчити студентів працювати 3 різними за жанром текстами, вміти не тільки створювати їх, а й модифікувати.

Вивчення мови у виші «здатне допомогти розвинути творче мислення студентів за рахунок використання специфічних лінгвістичних засобів і застосування сучасних інформаційних засобів. Творча активність правового мислення юристів полягає у створенні особливої мови як знакової системи, яка слугує засобом вираження правових понять, професійного спілкування, передачі професійного знання» (Лисенко, 2011: 18). Тому орієнтація навчального процесу саме на активну творчу розумову роботу студен- 
тів юридичних спеціальностей у контексті розвитку їхніх аналітико-конструктивних вмінь має стати найбільш значущим складником сучасної методики навчання мови за фахом.

Висновки. Можна зробити висновок про те, що формування лінгвістичної компетенції студентів юридичних спеціальностей - багатоаспектне i надзвичайно актуальне питання 3 точки зору лінгвістики і мовної освіти майбутніх юристів. На сучасному етапі завданням правової освіти $\epsilon$ не тільки викладання тих чи інших дисциплін, а й створення нової функціональної системи підготовки висококваліфікованого фахівця в галузі юриспруденції.

Нині випускник вищого навчального юридичного закладу повинен володіти отриманими загальнокультурними і професійними компетенціями, а саме правовою культурою, культурою професійного спілкування. Крім того, майбутній юрист повинен навчитися застосовувати знання, вміння та особисті якості відповідно до завдань професійної діяльності.

\section{СПИСОК ВИКОРИСТАНИХ ДЖЕРЕЛ}

1. Дроздова І. П. Формування мовної компетенції у студентів технічних спеціальностей вищих навчальних закладів Східної України (на матеріалі курсу ділової української мови) : автореф. дис. канд. пед. наук. Київ : Інститут педагогіки АПН України, 2001. 24 с.

2. Лисенко О. А. Мовна підготовка студентів юридичних спеціальностей відповідно до Болонської системи освіти. Наукові записки Національного університету «Острозька академія». Серія «Філологічна». Випуск 58. Острог : Нац. університет «Острозька академія». 2015. С. 34-37.

3. Українська мова (за правознавчим спрямуванням) : навч. посіб. / уклад.: О. А. Лисенко, В. М. Пивоваров, О. В. Прудникова, О. А. Шумейко. Харків : Нац. ун-т «Юрид. акад. України», 2011. 228 с.

4. Яшина Е. В. Особенности обучения студентов-юристов профессионально-ориентированному (юридическому) английскому языку как второму в рамках программы высшего образования. Вестник Саратовской государственной юридической академии. 2014. № 5 (100). С. 233-238.

\section{REFERENCES}

1. Drozdova I. P. Formuvannia movnoi kompetentsii u studentiv tekhnichnykh spetsialnostei vyshchykh navchalnykh zakladiv Skhidnoi Ukrainy (na materiali kursu dilovoi ukrainskoi movy) : avtoref. dys. kand. ped. nauk. [Formation of language competence in students of technical specialties of higher educational institutions of Eastern Ukraine (on the material of the course of business Ukrainian language) : author's ref. dis. Cand. ped. Science. Kyiv : Institute of Pedagogy of the Academy of Pedagogical Sciences of Ukraine, 2001. 24 p. [in Ukrainian].

2. Lysenko O. A. Movna pidhotovka studentiv yurydychnykh spetsialnostei vidpovidno do Bolonskoi systemy osvity. [Language training of law students in accordance with the Bologna system of education]. Scientific notes of the National University “Ostroh Academy”. Philological series. Issue 58. Jail: Nat. Ostroh Academy University. 2015. P. $34-37$ [in Ukrainian].

3. Ukrainska mova (za pravoznavchym spriamuvanniam) : navch. posib. [Ukrainian language (in the field of law) : textbook. way. / compiled by: O. A. Lysenko, V. M. Pivovarov, O. V. Prudnikova, O. A. Shumeiko]. Kharkiv : Nat. University of Law. acad. of Ukraine, 2011. 228 p. [in Ukrainian].

4. Yashyna E. V. Osobennosty obuchenyia studentov-yurystov professyonalno-oryentyrovannomu (iurydycheskomu) anhlyiskomu yazyku kak vtoromu v ramkakh prohrammy vyssheho obrazovanyia. [Features of teaching law students professionally-oriented (legal) English as a second language within the higher education program]. Bulletin of the Saratov State Law Academy. 2014. № 5 (100). P. 233-238 [in Russian]. 